\title{
Analysis of Organic Germanium Ge-132 as Cetane Improver in Diesel Combustion Process
}

\author{
S. Asri ${ }^{1}$, M. F. Othman' ${ }^{1}$, A. Abdullah ${ }^{1,2 *}$, Z. Abdullah ${ }^{1}$ and Z. Azmi ${ }^{1}$ \\ ${ }^{1}$ Faculty of Mechanical Engineering, Universiti Malaysia Pahang, \\ 26600 Pekan, Pahang, Malaysia \\ *Email: adam@ump.edu.my \\ Phone: +6094246353; Fax: +6094246345 \\ ${ }^{2}$ Automotive Engineering Centre, Universiti Malaysia Pahang, \\ 26600 Pekan, Pahang, Malaysia
}

\begin{abstract}
The depletion of global petroleum reserves and growth in awareness regarding the environmental pollution of diesel engines urge the reinforcement for the development of alternative fuels. This research experimentally investigated the effect of diesel-organic germanium (Ge-132, 2-Carboxyl Sesquioxide) fuels blend on combustion characteristics, engine performances and exhaust emissions on a direct injection diesel engine at the speed of $1800 \mathrm{rpm}$ at various brake effective pressures. On this occasion, the Ge-132 compound used in this experiment was widely utilized in the medical industry as a dietary supplement that contains therapeutic qualities such as oxygen enrichment, free radical scavenging, and immunity enhancement. Three fuel blends employed in this experiment were $\mathrm{Ge} 5, \mathrm{Ge} 8$, and Ge10 that are used to compare their performances with diesel fuel. In brief, the result stated that the fuel blend of Ge10 showed the highest value of cetane number, which was $8.23 \%$ higher compared to the diesel fuel followed by Ge8 and Ge5, which were 7.84 and $7.45 \%$ higher than the diesel fuel respectively. Besides, from the experiment, Ge5 decreased the value of BSFC by $26.6 \%$ compared to diesel fuel and improved the value of BTE that was $25.6 \%$ higher than the diesel fuel.
\end{abstract}

Keywords: Diesel engine; combustion, performance, emissions; organic germanium.

\section{INTRODUCTION}

The recent development of the economy, mainly in the industrial, energy, and transportation sectors intensified the need for energy such as natural energy, nuclear energy, hydraulic energy, coal and petroleum [1]. However, the ambient air quality is deteriorating year after year, which causes the occurrence of problems such as ozone holes, global warming, greenhouse effects, and acid rains. Indeed, these phenomena mainly occur due to the numerous productions of heavy industries, agricultural machines, and mass transportation, which mostly use the diesel engine as the prime mover [2]. Following the occurrence of these problems, many researchers intend to find out suitable solutions with an urgency to reduce the diesel engine exhaust emissions and to delay the depletion of global petroleum reserves. Researches include the improvement of the diesel engine technology via modification of injection parameter, exhaust gas after-treatment, and the development of environmentally friendly and renewable alternative fuels. Among various methods used, the alternative fuels are the most adequate and feasible technology 
to increase the diesel engine performance efficiently and reduce the exhaust emissions [3].

In the past several decades, a considerable amount of literature has been publishing topics on alternative fuels, involving the development of alternative fuels, including the usage of water-diesel emulsions in the diesel engine [4], biofuels from vegetable oils [5, 6], biofuels from waste cooking oil [7, 8], chemical additives [9, 10], and bio-alcohols $[11,12]$. Nevertheless, the process of making biofuels from vegetable oils includes the esterification process, which is too challenging to handle, and the produced ester properties face problems to meet the standards for the engine testing [13]. Hence, some researchers started to focus on experiments involving the effects of chemical additives in the duel such as metal-based, oxygenated, and antioxidant additives and cetane number improver [14]. Since the 1960s, the utilization of cetane number improver in the diesel fuel has been increasing due to the highest demand for diesel fuel relative to other petroleum products. In 1996, engine manufacturers increased the cetane number requirements, to assist them in manufacturing engines that can meet the Clean Air Act requirements [15]. Previous studies have reported that the addition of cetane enhancer of isoamyl nitrite was a key component that helped in ignition delay and premixed combustion duration recovered those of diesel fuel (DF) [16]. On top of that, Lu et al. stated in his study that the addition of cetane number improver in the ethanol-diesel blends improved the carbon monoxide (CO) and hydrocarbon (HC) emissions [17].

Recently, there is no reliable evidence in any literature that shows the usage of organic germanium products or in its scientific name as 2-Carboxyl Sesquioxide (Ge132) as an additive for DF or biodiesel fuel. Therefore, a detailed new study on the effect of Ge-132 as a cetane improver and its influence on the combustion characteristics, engine performance, and emissions of the diesel engine is called for. In the periodic table, germanium $(\mathrm{Ge})$ is an element inside the carbon group, which easily reacts with oxygen to form complex compound elements in nature [18]. In addition, Ge-132 is a mineral that contains germanium, carbon, hydrogen, and oxygen that can act as a potent pain reliever and enhancer of the immune system [19]. The main purpose of this study is to investigate the effects of diesel-organic germanium fuel blends on the combustion characteristics, performances, and emissions of the diesel engine. Throughout this experiment, the addition of Ge-132 is approximately 5, 8, and $10 \mathrm{mg}$ to 1 litre of DF. The test of the fuel blends on the direct injection diesel engine was at the constant engine speed of $1800 \mathrm{rpm}$ with various brake mean effective pressure (BMEP).

\section{RESEARCH METHODOLOGY}

\section{Test Engine and Instrumentation}

The experiment used YANMAR TF120M single cylinder, natural aspirated, water-cooled direct injection diesel engine (Table 1 shows the detailed specifications of the engine). The injection of DF was at $17^{\circ} \mathrm{CA}$ before top dead center (bTDC). Referring to the schematic diagram of the experimental set up shown in Figure 1, the eddy current dynamometer (Focus Applied Technologies model BD-15 kW) with the maximum power of $15 \mathrm{~kW}$ mounted in the spherical bearing was fitted directly to the test engine; an S-type load cell force sensor (Zemic H3-C3-500 kg-3B) was used to measure the brake torque of the diesel engine; a digital weight scale CAS (TCS - up to $6 \mathrm{~kg}$ ) was used to measure the fuel mass flow rate by recording the time required to consume a specific mass of the fuel; a thermocouple logger (PicoLog TC-08 USB) was used in this experiment 
functioning to measure the exhaust gas temperature, fuel temperature, and the ambient air temperature; an exhaust gas analyzer (QRO Technologies QRO-401) was built up with a different infra-red sensing cell, which was used in measuring the exhaust gas emissions of carbon monoxide $(\mathrm{CO})$, carbon dioxide $\left(\mathrm{CO}_{2}\right)$, oxygen $\left(\mathrm{O}_{2}\right)$, hydrocarbon $(\mathrm{HC})$ and nitrogen dioxide $\left(\mathrm{NO}_{\mathrm{x}}\right)$; and a crankshaft angle sensor was used to obtain the crankshaft position, which determines the cylinder gas pressure as the function of crank angle.

Table 1. Details of engine specifications.

\begin{tabular}{ll}
\hline Properties & Value \\
\hline Engine type & YANMAR TF120M \\
Number of cylinder & 1 \\
Bore x Stroke & $92 \times 96 \mathrm{~mm}$ \\
Displacement & $0.638 \mathrm{~L}$ \\
Compression ration & 17.7 \\
Injection timing & $17^{\circ} \mathrm{bTDC}$ \\
Continuous output & $10.5 \mathrm{HP}$ at $2400 \mathrm{rpm}$ \\
Rated output & $12 \mathrm{HP}$ at $2400 \mathrm{rpm}$ \\
Cooling system & Water-cooled \\
\hline
\end{tabular}

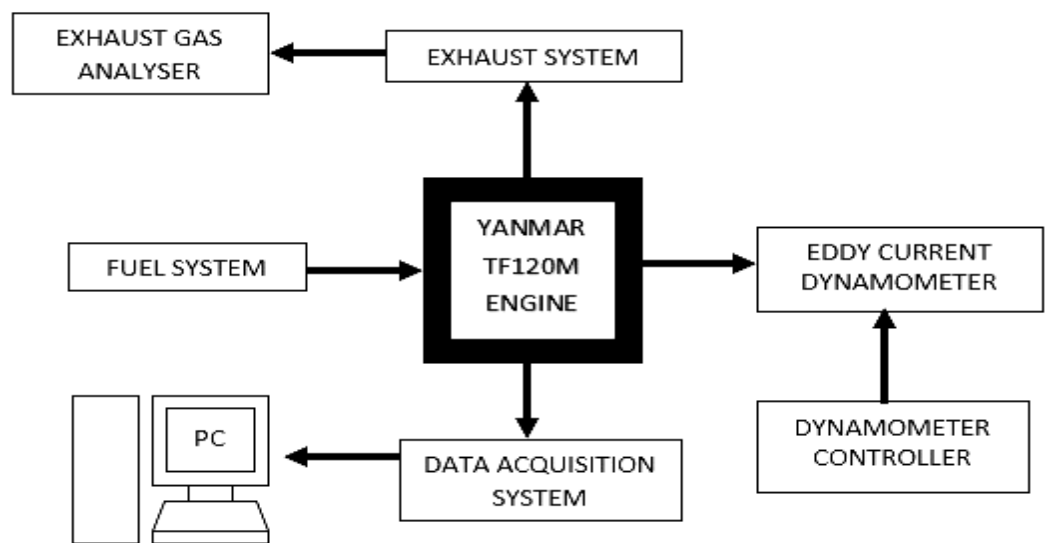

Figure 1. Schematic diagram of the experimental setup for a single cylinder diesel engine.

\section{Engine Test Cycle and Test Procedures}

In brief, the comparison of the outcome data was calculated between the three test fuels used in this experiment with DF. These test fuels were Ge5, Ge8, and Ge10, which referred to the addition of 5,8 and $10 \mathrm{mg}$ of Ge-132, blended in 1 litre of DF respectively. Ultrasonic emulsifier machine (Hielscher Ultrasonic GmbH, UP400S) used in this experiment to mix the diesel-organic germanium fuel blended at $60 \% \mathrm{~Hz}$ stirring speed. The preparation of fuel properties characterizations was strictly done by following the ASTM-D6751-08 guidelines and meet the EN14214 standard specifications. All the data were collected and processed by using the data acquisition of engineering software (DEWESOFT X2). The parameters measured and analysed in this experiment were combustion characteristics, engine performance, and exhaust emissions. This experiment 
was carried out at the constant speed of $1800 \mathrm{rpm}$, with various BMEP. Table 2 shows the result of the physiochemical properties of each test fuels.

Table 2. Details of the fuel properties of tested blends.

\begin{tabular}{lccccc}
\hline Parameter & Unit & DF & Ge5 & Ge8 & Ge10 \\
\hline Viscosity & $\mathrm{mm}^{2} / \mathrm{s}$ & 3.12 & 3.49 & 3.52 & 3.51 \\
Density & $\mathrm{kg} / \mathrm{m}^{3}$ & 828.69 & 842.30 & 844.85 & 850.25 \\
Calorific value & $\mathrm{MJ} / \mathrm{kg}$ & 44.8 & 48.5 & 48.6 & 49.2 \\
Cetane number & - & 51.0 & 54.8 & 55.0 & 55.2 \\
\hline
\end{tabular}

\section{RESULTS AND DISCUSSION}

This investigation involved the comparison on performance, combustion, and emission characteristics between DF and the diesel-organic germanium fuel blends. The result for combustion characteristics of peak in-cylinder pressure was plotted with the position of crank angle against the BMEP value. Meanwhile, for engine performance and exhaust emissions, the data was plotted against the BMEP reading.

\section{Combustion Characteristics - In-Cylinder Peak Pressure}

Figure 2 shows the reading of in-cylinder peak pressure of the diesel engine fuelled with diesel-organic germanium blends and DF at the speed of $1800 \mathrm{rpm}$ with various BMEP readings. From this figure, as the BMEP of the engine increases, the in-cylinder peak pressure increases as well. For instance, from the graph, the reading of in-cylinder peak pressure for Ge10 shows an increment of $25.4 \%$ from the lowest (35 kPa) to the highest $(637 \mathrm{kPa}) \mathrm{BMEP}$ reading. This result can be explained by the fact that additional fuel was sprayed into the cylinder to cause a high rate of combustion at the highest BMEP value [20]. Meanwhile, at $0 \%$ of the load of BMEP value ranging from $34 \mathrm{kPa}$ to $67 \mathrm{kPa}, \mathrm{Ge} 5$ shows the lowest peak pressure followed by DF, Ge8, and Ge10. The peak pressure of Ge5 decreases approximately by $1.92 \%$ compared to DF, whereas Ge8 shows the highest peak pressure at approximately 3.23\% higher compared to DF. This result attributes to the higher viscosity of $\mathrm{Ge} 8$ that caused poor atomization which delayed the start of premixed combustion and increased the combustion rate after the delayed start [21].

On the other hand, at the load of $25 \%$ to $100 \%$ of the BMEP reading ranging from $104 \mathrm{kPa}$ to $638 \mathrm{kPa}$, the figures show that $\mathrm{Ge} 10$ has the highest value of peak pressure compared to the other blended fuels used in this experiment. This correlation is related to the properties of Ge-132 which is an oxygenated compound that helps in improving the combustion of the engine. Sathiyamoorthi et al. [22] stated in his study that the usage of ethanol which has an oxygenated content, can result in a rapid pressure rise and peak cylinder pressure due to the diesel engine getting additional oxygen to burn, when more oxygenated fuel is accumulated during the delay period. 


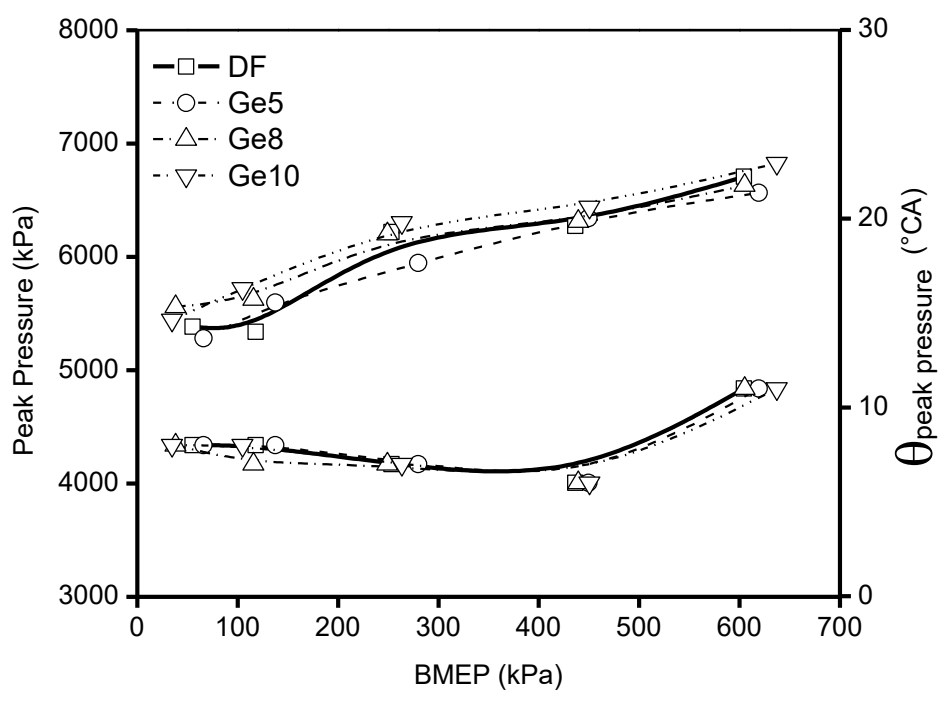

Figure 2. Peak pressure behaviour and crank angle for various BMEP at $1800 \mathrm{rpm}$.

\section{Engine Performance - BSFC and BTE}

Figure 3 illustrates the brake specific fuel consumption (BSFC) characteristics for various blended fuels used in the experiments. The value of BSFC gradually decreases with the increase of the BMEP reading. For example, the BSFC value of Ge8 from the lowest BMEP $(38 \mathrm{kPa})$ to the highest BMEP $(605 \mathrm{kPa})$ decreases to $75.6 \%$ significantly. The result obtained has been reported previously by Kotebavi et al. [23] in his experiment in which he stated that at the highest load, the increasing temperature of the cylinder wall can reduce the ignition delay. Thus, shortening ignition delay will lead to an improvement in combustion and a reduction in fuel consumption. From the figure shown, a remarkable result can be seen at the lowest BMEP of the diesel engine that shows Ge10 has the highest BSFC value, which is $67.5 \%$ higher than DF. As stated in the previous study by Devan et al. [24] the reason for the highest BSFC reading is due to the difference in the density and the heating value of the blend fuels and DF.

In Table 2, despite having the highest calorific value which is $9.2 \%$ higher than $\mathrm{DF}$, the percentage difference of viscosity for Ge10 and DF is larger which is $12.5 \%$ higher compared to DF, thus affecting the BSFC performance of Ge10. This finding corroborated the ideas of Attia et al. [25] who stated that the reading of BSFC is increased due to the higher viscosity and density of the blended fuels in order to reimburse the worsening of fuel atomization and combustion inequality. On the contrary, despite having the lowest peak pressure, Ge5 showed the lowest BSFC value which is $26.6 \%$ lower compared to DF. According to Table 2, the value of cetane number of Ge5 is $7.45 \%$ higher compared to DF which reflects the findings of Lin et al. [26] who stated that the fuel with higher cetane index has a superior compression ignition quality in the diesel engine and thus provide a better combustion characteristic. 


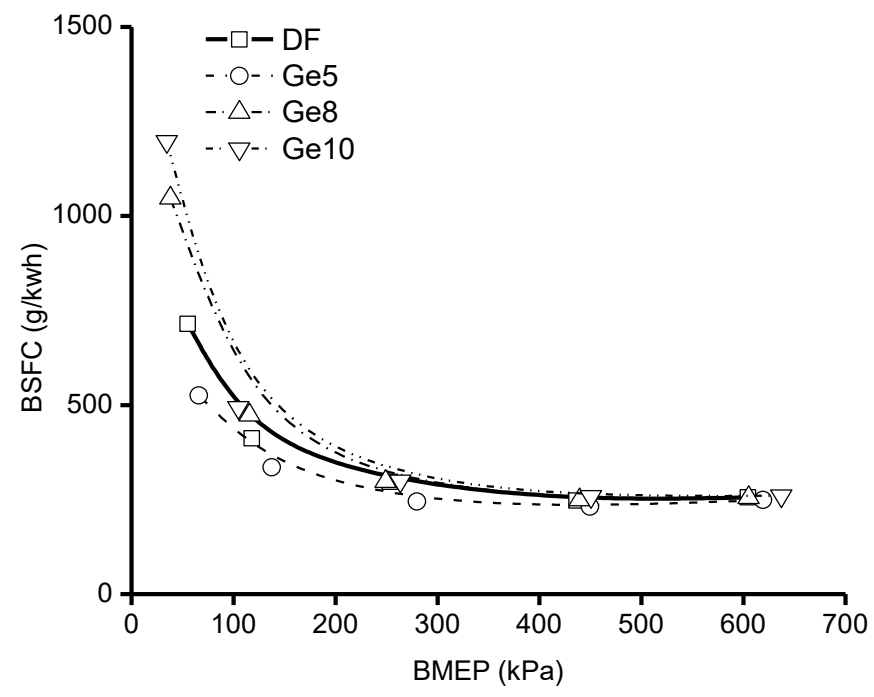

Figure 3. BSFC behaviour for various BMEP at $1800 \mathrm{rpm}$.

Figure 4 shows the reading of brake thermal efficiency (BTE) for various BMEP values at the speed of $1800 \mathrm{rpm}$. The figure illustrates that the BTE increases with the increase of BMEP value and drops significantly at the load of $75 \%$ at which the BMEP value ranges from 436 to $451 \mathrm{kPa}$. In this case, the figure shows that at the lowest load, the value of BTE for Ge10 is $6.27 \%$ which then increases to $28.7 \%$ at the load of $75 \%$ and decreases to $28.4 \%$ at the highest load. The result obtained reflects the findings of Babu et al. [27], who stated in his experiment that BTE increased up to $80 \%$ and then decreased when the engine load increased. Concurrently, this was due to the accumulation of the duel in the combustion chamber caused by the larger amount of fuel injected at full load condition, which led to the possibility of incomplete combustion. Meanwhile, at the load of 50\%, which the BMEP ranged from 249 to $281 \mathrm{kPa}, \mathrm{Ge} 5$ had the highest BTE which was $12.74 \%$ higher than DF respectively. Referring to Table 2, Ge5 has a higher heating value of $8.25 \%$ compared to DF, which improves the BTE of the engine. In brief, this finding corroborates with the ideas of Saleh et al. [28] who stated that the oxygen content of the fuel blends helped in increasing the combustion efficiency and decreased the heat losses in the cylinder.

\section{Emission - $\mathrm{CO}, \mathrm{CO}_{2}, \mathrm{O}_{2}$, and $\mathrm{NO}_{x}$}

Figure 5 shows the $\mathrm{CO}$ emission for the variances of BMEP reading at the speed of 1800 rpm for all the fuel blends used in this experiment. From the graph, it is observed that the $\mathrm{CO}$ emission increased from the lowest BMEP to the highest BMEP of the diesel engine. For instance, as shown in the graph, the value of $\mathrm{CO}$ emission for Ge8 increases from 0.02 to $0.07 \%$. Previously, Venu et al. [29] stated that at the highest load, more fuel would enter the cylinders of the engine. Afterward, when more fuel with less energy content took part in the combustion, incomplete combustion occured and resulted in higher CO emission. On the contrary, throughout the operating conditions of the engine, DF had the lowest $\mathrm{CO}$ emission. As an example, at the highest BMEP reading, the difference in value of Ge5 compared to DF was approximately $11.7 \%$ higher than DF. In accordance with the present result, previous studies done by Lu et al. [17] demonstrated that the incomplete combustion of the blended fuels led to the increase of CO emission level. 


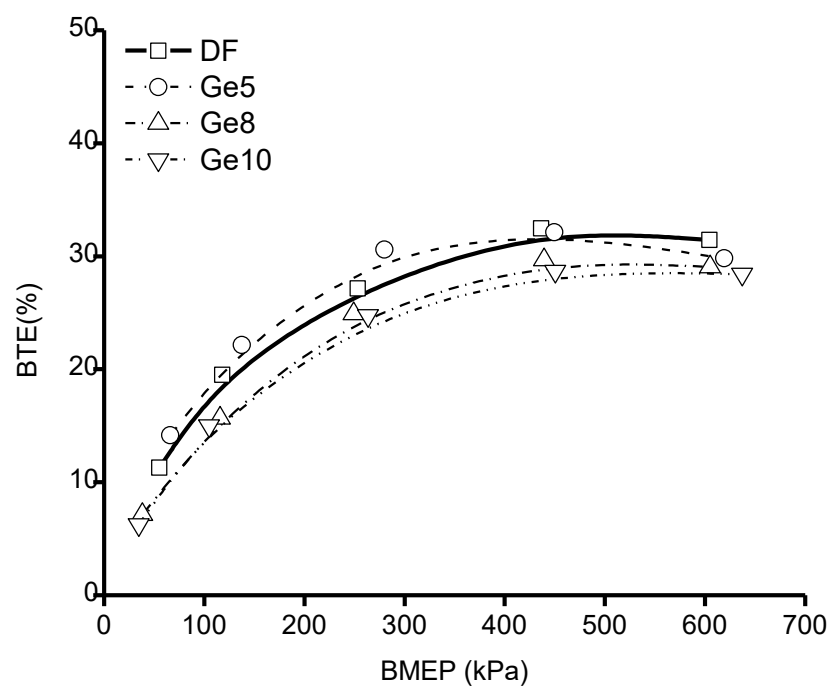

Figure 4. BTE behaviour with various BMEP at $1800 \mathrm{rpm}$.

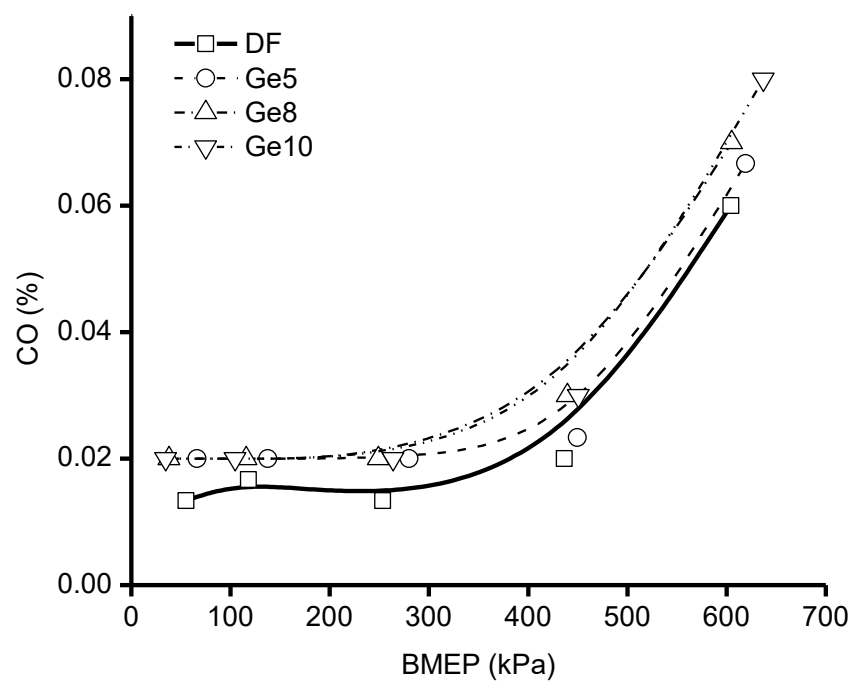

Figure 5. CO emission behaviour for various BMEP at $1800 \mathrm{rpm}$.

In another case, Figure 6 illustrates that as the BMEP value of the engine increases, the emission of $\mathrm{CO}_{2}$ increases. It can also be observed that $\mathrm{CO}_{2}$ emission increases as the value of Ge-132 inside DF increases. According to the figure, at the load of $75 \%$, where the BMEP range from 436 to $451 \mathrm{kPa}, \mathrm{Ge} 8$ has the highest $\mathrm{CO}_{2}$ emission which is $1.08 \%$ higher compared to Ge5. This result is supported by Sakthivel et al. [30] who stated that as the $\mathrm{CO}_{2}$ emission increased, the blended fuel proportion increased due to the higher oxygen content inside the blends which enhanced the fuel blends being burned efficiently than DF. On top of that, throughout the experiment, the figure shows that $\mathrm{Ge} 10$ has the highest $\mathrm{CO}_{2}$ emission compared to DF. This can be seen clearly at the highest BMEP that the $\mathrm{CO}_{2}$ emission is $10.6 \%$ higher than DF. This finding can be explained by the fact that the fuel-bound oxygen is now assisting the $\mathrm{CO}$ oxidation to $\mathrm{CO}_{2}$ [31]. The utilization of the excess oxygen in the oxygen combustion chamber improves the combustion process that enhances the conversion of $\mathrm{CO}$ to $\mathrm{CO}_{2}$ [31]. 


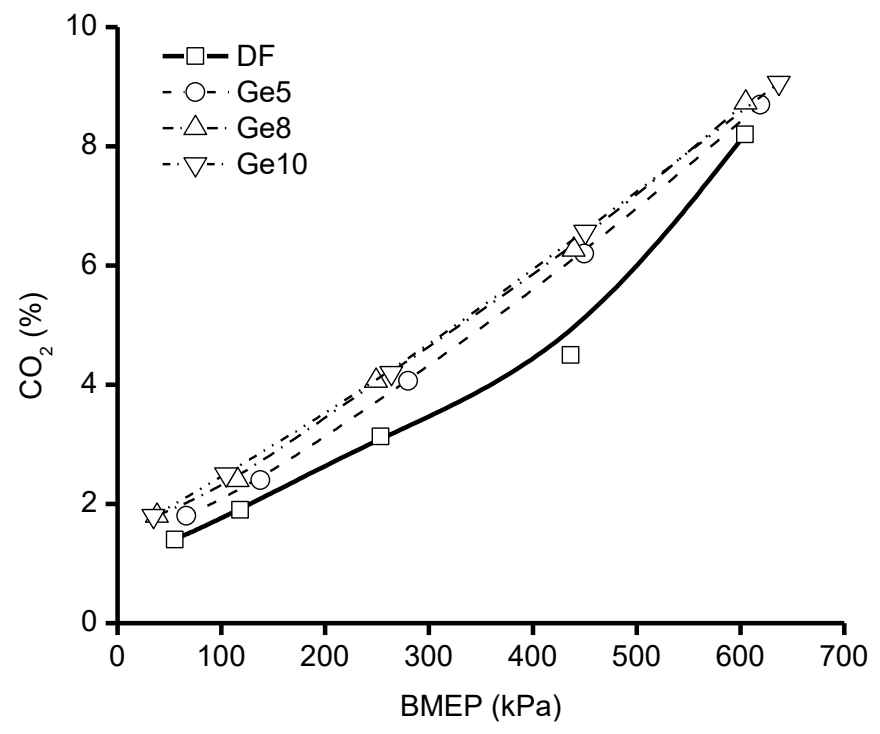

Figure 6. $\mathrm{CO}_{2}$ emission behaviour for different BMEP at $1800 \mathrm{rpm}$.

One can observe in Figure 7 the variations of $\mathrm{O}_{2}$ concentration in the exhaust emission against the different BMEP of the engine at the speed of $1800 \mathrm{rpm}$. From the figure, $\mathrm{O}_{2}$ emission decreases with the increase of the BMEP of the engine. As example, from the lowest BMEP to the highest $\mathrm{BMEP}$, the value $\mathrm{O}_{2}$ emission for $\mathrm{Ge} 8$ decreases to $52.5 \%$. Moreover, it can be observed throughout the experiment that DF has the highest $\mathrm{O}_{2}$ emission compared to the fuel blends. On the contrary, Ge10 shows the lowest $\mathrm{O}_{2}$ emission compared to DF. At the highest reading of BMEP, the value of $\mathrm{O}_{2}$ emission for Ge10 is $11.3 \%$ lower compared to DF. Overall, as stated by Patnaik et al. [32] in his previous experiment, the utilization of the excess oxygen in the combustion chamber helps in improving the combustion of the fuel blends.

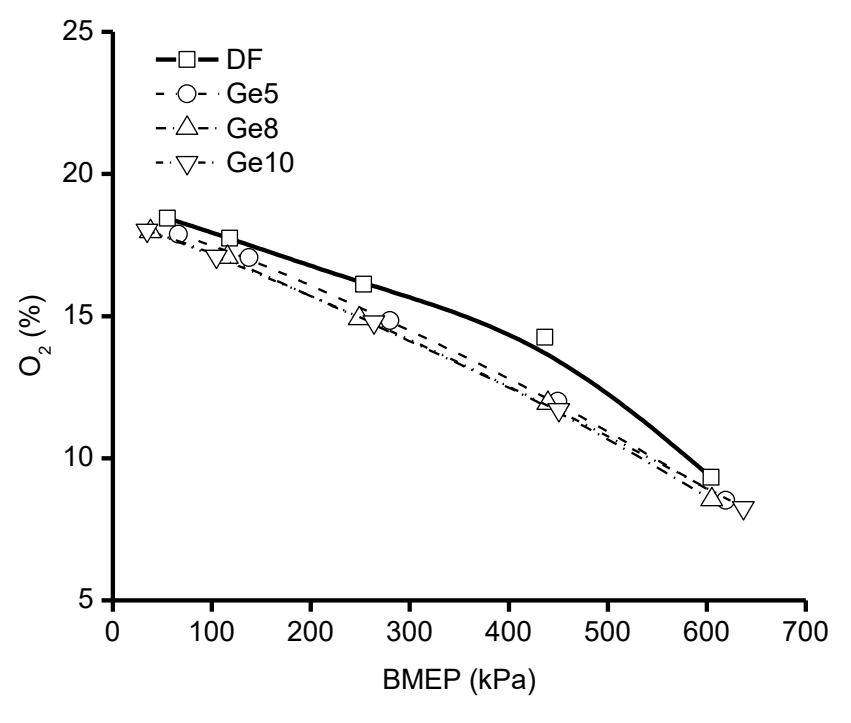

Figure 7. $\mathrm{O}_{2}$ emission behaviour for different BMEP at $1800 \mathrm{rpm}$.

The factors that lead to the formation of $\mathrm{NO}_{\mathrm{x}}$ emissions are the high temperature and oxygen enrichment of the fuel blends. The $\mathrm{NO}_{\mathrm{x}}$ emissions of the blended fuels at the selected operating conditions are shown in Figure 8. The result of this study indicates that 
the emission of $\mathrm{NO}_{\mathrm{x}}$ increases as the value of BMEP of the engine increases. In this case, from the figure, the value of $\mathrm{NO}_{\mathrm{x}}$ emission for $\mathrm{Ge} 5$ increases to $26.1 \%$ from the lowest BMEP to the highest BMEP. These findings support the idea of Huang et al. [33] who stated that the increase in BMEP would provide the high temperature environment required for the formation of $\mathrm{NO}_{\mathrm{x}}$ emission. This is attributed to when the value of BMEP increases, the temperature of the in-cylinder combustion will become higher and thus increases the injection of the fuel quantity per cycle. In contrast, the graph shows that throughout the experiments of the diesel engine, DF has the lowest $\mathrm{NO}_{\mathrm{x}}$ emission compared to the blend fuels. However, the difference between the fuel blends and DF is not vastly different. For example, at the highest load, all the blended fuels; Ge5, Ge8 and Ge10 is approximately $1.17 \%, 3.33 \%$ and $6.23 \%$ higher compared to DF. This present finding seems to be consistent with Damodharan et al. [34] who found that $\mathrm{NO}_{\mathrm{x}}$ emission increased gradually with the increasing concentration of n-butanol fuel due to the increased oxygen content in the blend fuels. As mentioned before, Ge-132 acts as the oxygenated compound, which helps in setting for the $\mathrm{NO}_{\mathrm{x}}$ emission development.

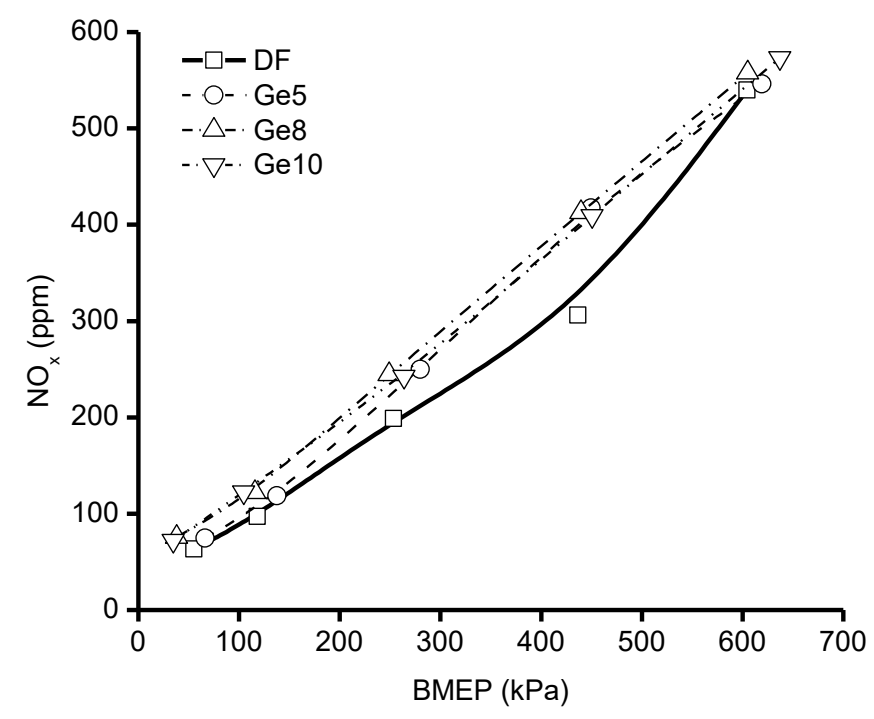

Figure 8. $\mathrm{NO}_{\mathrm{x}}$ emission behaviour for different $\mathrm{BMEP}$ at $1800 \mathrm{rpm}$.

\section{CONCLUSION}

The purpose of the current study is to determine the effect of diesel-organic germanium blend on the combustion characteristics, performance and emissions of the diesel engine at the constant engine speed of $1800 \mathrm{rpm}$ with various BMEP readings. Throughout the whole experimental analysis, the following conclusions can be stated:

i. The fuel blends have higher cetane number compared to DF and is therefore suitable to be used as the cetane improver, which (Both Ge5 and Ge 8 have a higher value cetane number of $7.45 \%$ compared to DF. Meanwhile, Ge10 is $8.24 \%$ higher than DF).

ii. The value of BTE for the blend fuels improves at the lowest load, at which Ge10 has $79.9 \%$ higher value of BTE compared to DF. On the contrary, the addition of Ge-132 inside DF increases the BSFC of the engine at the lowest load, at which the value of BSFC for Ge10 is $67.5 \%$ higher than DF.

iii. The production of $\mathrm{O}_{2}$ and $\mathrm{CO}_{2}$ emissions shows that the addition of $\mathrm{Ge}-132$ improves the combustion performance of the fuel. However, Ge-132 increases the 
emission of $\mathrm{CO}$ and $\mathrm{NO}_{\mathrm{x}}$ but in a slightly different value compared to DF. For instance, at the highest load, Ge5, Ge8 and Ge10 is $1.17 \%, 3.33 \%$ and $6.23 \%$ higher compared to DF.

The results suggest that the most promising blend as an alternative fuel for DF is Ge5 due to its effect on engine performance and emissions. Ge5 decreases the BSFC of the diesel engine; while Ge8 and Ge10 show the highest reading of BSFC than the DF. $\mathrm{Ge} 5$ also increases $\mathrm{NO}_{\mathrm{x}}$ of the diesel engine slightly, but not more than that of the diesel fuel.

\section{ACKNOWLEDGEMENT}

The authors would like to acknowledge the support of the Power Engine Lab, Faculty of Mechanical Engineering. This work was partly supported by UMP Research Grant Scheme RDU1603100.

\section{REFERENCES}

[1] Correa SM, Arbilla G. Carbonyl emissions in diesel and biodiesel exhaust. Atmospheric environment. 2008;42:769-75.

[2] Labeckas G, Slavinskas S. The effect of rapeseed oil methyl ester on direct injection diesel engine performance and exhaust emissions. Energy Conversion and Management. 2006;47:1954-67.

[3] Annamalai M, Dhinesh B, Nanthagopal K, SivaramaKrishnan P, Lalvani JIJ, Parthasarathy $\mathrm{M}$, et al. An assessment on performance, combustion and emission behavior of a diesel engine powered by ceria nanoparticle blended emulsified biofuel. Energy Conversion and Management. 2016;123:372-80.

[4] Syafiq Z, Fahmi O, Awad OI, Adam A. The study of stability, combustion characteristics and performance of water in diesel emulsion fuel. MATEC Web of Conferences: EDP Sciences; 2017. p. 01022.

[5] Ashok B, Raj RTK, Nanthagopal K, Krishnan R, Subbarao R. Lemon peel oil-A novel renewable alternative energy source for diesel engine. Energy Conversion and Management. 2017;139:110-21.

[6] Raheman H, Ghadge S. Performance of compression ignition engine with mahua (Madhuca indica) biodiesel. Fuel. 2007;86:2568-73.

[7] Adam A, Ramlan NA, Jaharudin NF, Hamzah H, Othman MF, Mrwan AAG. Analysis of combustion characteristics, engine performance and exhaust emissions of diesel engine fueled with upgraded waste source fuel. International Journal of Hydrogen Energy. 2017.

[8] Othman MF, Adam A, Najafi G, Mamat R. Green fuel as alternative fuel for diesel engine: A review. Renewable and Sustainable Energy Reviews. 2017;80:694-709.

[9] Rashedul HK, Kalam MA, Masjuki HH, Teoh YH, How HG, Monirul IM, et al. Attempts to minimize nitrogen oxide emission from diesel engine by using antioxidant-treated diesel-biodiesel blend. Environmental Science and Pollution Research. 2017;24:9305-13.

[10] Prabu SS, Asokan M, Roy R, Francis S, Sreelekh M. Performance, combustion and emission characteristics of diesel engine fuelled with waste cooking oil biodiesel/diesel blends with additives. Energy. 2017;122:638-48.

[11] Alptekin E. Emission, injection and combustion characteristics of biodiesel and oxygenated fuel blends in a common rail diesel engine. Energy. 2017;119:44-52. 
[12] Wei M, Li S, Xiao H, Guo G. Combustion performance and pollutant emissions analysis using diesel/gasoline/iso-butanol blends in a diesel engine. Energy Conversion and Management. 2017;149:381-91.

[13] Can O, Ozturk E, Yucesu HS. Combustion and exhaust emissions of canola biodiesel blends in a single cylinder DI diesel engine. Renewable Energy. 2017;109:73-82.

[14] Kumar MV, Babu AV, Kumar PR. The impacts on combustion, performance and emissions of biodiesel by using additives in direct injection diesel engine. Alexandria Engineering Journal. 2017.

[15] Suppes G, Rui Y, Rome A, Chen Z. Cetane-improver analysis and impact of activation energy on the relative performance of 2-ethylhexyl nitrate and tetraethylene glycol dinitrate. Industrial \& Engineering Chemistry Research. 1997;36:4397-404.

[16] Ren Y, Huang Z, Jiang D, Li W, Liu B, Wang X. Effects of the addition of ethanol and cetane number improver on the combustion and emission characteristics of a compression ignition engine. Proceedings of the Institution of Mechanical Engineers, Part D: Journal of Automobile Engineering. 2008;222:1077-87.

[17] Lü XC, Yang JG, Zhang WG, Huang Z. Improving the combustion and emissions of direct injection compression ignition engines using oxygenated fuel additives combined with a cetane number improver. Energy \& Fuels. 2005;19:1879-88.

[18] Syafiq Z, Fahmi O, Syuhaida N, Chen AF, Adam A. Diesel engine performance and exhaust emission analysis using diesel-organic germanium fuel blend. MATEC Web of Conferences: EDP Sciences; 2017. p. 01053.

[19] Moskalyk R. Review of germanium processing worldwide. Minerals Engineering. 2004;17:393-402.

[20] Kaimal VK, Vijayabalan P. An investigation on the effects of using DEE additive in a DI diesel engine fuelled with waste plastic oil. Fuel. 2016;180:90-6.

[21] Kaimal VK, Vijayabalan P. A detailed study of combustion characteristics of a DI diesel engine using waste plastic oil and its blends. Energy Conversion and Management. 2015;105:951-6.

[22] Sathiyamoorthi R, Sankaranarayanan G. The effects of using ethanol as additive on the combustion and emissions of a direct injection diesel engine fuelled with neat lemongrass oil-diesel fuel blend. Renewable Energy. 2017;101:747-56.

[23] Kotebavi V, Sahu D, Shetty D. Performance and emission characteristics of a CI engine run on waste cooking oil-diesel blends. Pollution Research. 2016;35:15966.

[24] Devan P, Mahalakshmi N. Performance, emission and combustion characteristics of poon oil and its diesel blends in a DI diesel engine. Fuel. 2009;88:861-7.

[25] Attia AM, Hassaneen AE. Influence of diesel fuel blended with biodiesel produced from waste cooking oil on diesel engine performance. Fuel. 2016;167:316-28.

[26] Lin CY, Lin HA. Diesel engine performance and emission characteristics of biodiesel produced by the peroxidation process. Fuel. 2006;85:298-305.

[27] Babu D, Anand R. Effect of biodiesel-diesel-n-pentanol and biodiesel-diesel-nhexanol blends on diesel engine emission and combustion characteristics. Energy. 2017;133:761-76.

[28] Saleh H, Selim MY. Improving the performance and emission characteristics of a diesel engine fueled by jojoba methyl ester-diesel-ethanol ternary blends. Fuel. 2017;207:690-701. 
[29] Venu H, Madhavan V. Influence of diethyl ether (DEE) addition in ethanolbiodiesel-diesel (EBD) and methanol-biodiesel-diesel (MBD) blends in a diesel engine. Fuel. 2017;189:377-90.

[30] Sakthivel G, Nagarajan G, Ilangkumaran M, Gaikwad AB. Comparative analysis of performance, emission and combustion parameters of diesel engine fuelled with ethyl ester of fish oil and its diesel blends. Fuel. 2014;132:116-24.

[31] Dhanasekaran R, Krishnamoorthy V, Rana D, Saravanan S, Nagendran A, Kumar BR. A sustainable and eco-friendly fueling approach for direct-injection diesel engines using restaurant yellow grease and n-pentanol in blends with diesel fuel. Fuel. 2017;193:419-31.

[32] Patnaik PP, Jena SP, Acharya SK, Das HC. Effect of FeCl 3 and diethyl ether as additives on compression ignition engine emissions. Sustainable Environment Research. 2017;27:154-61.

[33] Huang H, Liu Q, Teng W, Pan M, Liu C, Wang Q. Improvement of combustion performance and emissions in diesel engines by fueling n-butanol/diesel/PODE34 mixtures. Applied Energy. 2017.

[34] Damodharan D, Sathiyagnanam A, Rana D, Kumar BR, Saravanan S. Extraction and characterization of waste plastic oil (WPO) with the effect of n-butanol addition on the performance and emissions of a DI diesel engine fueled with WPO/diesel blends. Energy Conversion and Management. 2017;131:117-26. 